\title{
Public Health and Global Climate Disruption
}

\author{
Jonathan A. Patz, MD, MPH, ${ }^{1}$ \\ Melissa J. Hatch, MA ${ }^{2}$
}

\begin{abstract}
Climate change presents a significant challenge to global health. This paper examines the health impacts of climate change from extreme weather events, temperature changes, rising sea levels and changes in precipitation. These health impacts include heat-related illnesses and deaths, air pollution-related health effects, allergic diseases, infectious diseases, malnutrition, and disasters associated with extreme weatherrelated health effects such as hurricanes, tornadoes, droughts, fires, heavy precipitation, storms and flooding. Most populations will be impacted by climate change in the next decades, putting peoples' lives and wellbeing at risk. Vulnerable populations across the globe will be impacted disproportionately due to climate change. It is populations that are often least responsible for climate change that experience the greatest adverse impacts, raising important moral issues of equity and fairness. In addition to reviewing the literature on the health impacts of climate change, this paper will examine issues of inequity across vulnerable populations and generations due to climate change, the health co-benefits of greenhouse gas mitigation, and potential options for adaptation to increasingly extreme weather events.
\end{abstract}

Key Words: Global climate disruption, public health, climate change, health impacts, disease, vulnerable populations, equity

Recommended Citation: Patz JA, Hatch MJ. Public health and global climate disruption. Public Health Reviews. 2014;35: epub ahead of print.

\footnotetext{
${ }^{1}$ University of Wisconsin-Madison-Global Health Institute, Nelson Institute for Environmental Studies, Department of Population Health Sciences, and the Center for Sustainability \& the Global Environment (SAGE), WI, USA.

${ }^{2}$ University of Wisconsin-Madison, Nelson Institute for Environmental Studies - Center for Sustainability \& the Global Environment (SAGE), WI, USA.
}

Corresponding Author Contact Information: Dr. Jonathan Patz at patz@wisc.edu; University of Wisconsin-Madison - Global Health Institute, Nelson Institute for Environmental Studies, Department of Population Health Sciences, and the Center for Sustainability \& the Global Environment (SAGE), WI, USA. 


\section{INTRODUCTION}

Climate change is one of the largest global health threats of the $21^{\text {st }}$ century. According to the United Nations Intergovernmental Panel on Climate Change (IPCC), warming of the earth's climate is "unequivocal" and human influence of the climate system is clear. ${ }^{1}$ The IPCC estimates about a two degrees Celsius rise in global average warming by the end of the century. Anticipated climate change will impact the environment and health of most populations in the next decades and put the lives and wellbeing of billions of people at increased risk. Vulnerable populations will be impacted disproportionately, raising moral concerns of equity and fairness. Those that are often the least responsible for climate change, experience the greatest adverse impacts. This paper reviews the literature on the health impacts of climate change, issues of inequity across vulnerable populations and generations, the health co-benefits of greenhouse gas mitigation, and potential options for adaptation to increasingly extreme weather events.

\section{UPDATE ON THE HEALTH IMPACTS OF CLIMATE CHANGE}

There are many pathways by which climate change can impact health. First, climate change effects regional and local weather change, causing extreme weather events, temperature changes, and precipitation. Regional and local weather changes effect air pollution concentration and distribution, pollen production, microbial contamination and transmission, and crop yields. These changes can produce the following health impacts: (1) heatrelated illnesses and deaths, (2) disasters associated with extreme weatherrelated health effects (from hurricanes, tornadoes, droughts, fires, heavy precipitation, storms, and flooding), (3) air pollution-related health effects, (4) allergic diseases, (5) infectious diseases (especially those that are waterfood-, or vector-borne diseases), and (6) malnutrition. ${ }^{2}$

Secondly, climate change results in raised sea levels, with coastal flooding and changes in coastal aquifer salinity. Global mean sea level has risen approximately $20 \mathrm{~cm}$. over the past century. ${ }^{1}$ These changes can impact health, as well, causing storm surge-related drowning and injuries, and substantial disease burden for displaced populations. ${ }^{2}$

\section{Heat-related IIlnesses and Deaths}

Increases in air temperature cause mortalities and illness during heat waves and summer extremes. In the United States, heat waves kill more people than hurricanes, floods, and tornadoes combined. ${ }^{3}$ This is because the 
human body's ability to respond to heat stress is limited by the capacity to increase cardiac output as required for greater cutaneous blood flow to cool the body. ${ }^{3}$ Heat wave mortality is related to cardiovascular, cerebrovascular, and respiratory diseases mainly among vulnerable groups, such as elderly persons and individuals with preexisting illness.

Climate change scenarios predict increases in the frequency and intensity of extreme heat events in the future, and population health may be significantly compromised for people who cannot reduce their heat exposure. ${ }^{4}$ One study projected the effect of a few degrees of climate change on Australians in 2070. It projects that outdoor activity will not be possible on 33-45 days per year, compared to four to six days per year at present for un-acclimatized people, and that leisure activities like outdoor play for children for acclimatized people will not be possible on five to 14 days per year in 2070 compared to one day in five years at present. ${ }^{5}$

Occupational exposures to excessive heat are dangerous to outdoor workers. During the summer season, outdoor workers are affected by the heat exposures and subsequent economic impacts of reduced work capacity can be substantial. ${ }^{6}$ According to modeling by Kjellstrom et al. (2009), by the 2050s, as high as 15 to 18 percent of work days could be lost due to heat in Southeast Asia, West and Central Africa and Central America. ${ }^{7}$

Each year in the US, there are on average about 658 deaths that can be classified as directly attributable to heat-related causes. ${ }^{8}$ Larger effects of heat and heat waves occur earlier in the hot season. ${ }^{9,10}$ Chicago's Upper Midwest heat wave caused 700 excess deaths in July 1995. ${ }^{11}$ Currently for the US, mortality increases nearly four percent during heat wave days compared with non-heat wave days, by 2.5 percent for every one degree Fahrenheit increase in heat wave intensity, and by 0.4 percent for every one-day increase in heat wave duration. ${ }^{9}$ In 2003, a European heat wave killed at least 40,000 people in just two weeks across twelve countries. ${ }^{12}$ This heat wave greatly impacted vulnerable groups such as the old and the ill. ${ }^{13,14}$ How the growing aging population live in cities will be a challenge for the future in a warming world because housing and social integration play a large role on the impacts of the elderly in heat waves. ${ }^{13}$ The 2003 heat wave evidences that how we build our cities and integrate vulnerable groups of people socially impacts human health in extreme heat. ${ }^{13,14}$

According to Hayhoe et al. (2010), before the end of the $21^{\text {st }}$ century 1995-like heat waves could occur every other year on average under a conservative low emissions scenario. ${ }^{15}$ Another study found heat waverelated mortality in Chicago would increase to between 166 and 2,217 excess deaths per year based on estimates from seven global climate models for the period 2081-2100. ${ }^{16}$ Analysis of past heat wave admissions to hospitals in 
the city of Milwaukee shows endocrine, genitourinary, respiratory disorders, and self-harm (suicide attempts) correlated with hot temperatures. ${ }^{17}$ This correlation is significant for each of the outcomes, and is shown in the figure below. Heat response plans and heat early warning systems (EWS) can save lives with expected temperatures rise in the coming decades. ${ }^{18}$ However, from a US-based survey administered to 285 communities in 2009 , of 70 respondents only 30 local governments have established heat wave health prevention effect programs. ${ }^{19} \mathrm{An}$ increase in heat wave health prevention and preparedness programs would be extremely beneficial for public health.
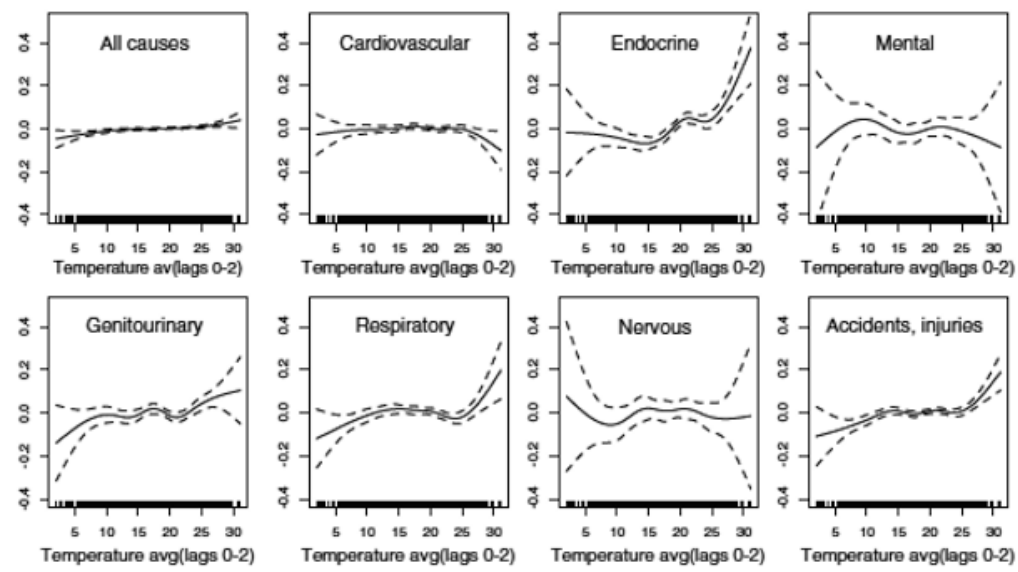

Fig. 1. The above figures show the relationship between hospital admissions and heat waves in the city of Milwaukee, Wisconsin. There is a correlation with hot temperatures and hospital admissions for endocrine, genitourinary, respiratory disorders, and self-harm. The temperature here refers to the average mean temperature 0-2 days preceding hospital admission. The smoothed line shows the relationship between temperature and hospital admissions by cause and age group. The spline curves reveal the relative risk of hospital admission for temperatures across each range. The solid line is the estimated spline curve, and the dashed lines surrounding the solid line are its $95 \%$ confidence limits. The ticks in the x-axis show the occurrence of each " $x$ ".

Source: Li B, Sain S, Mearns L, Anderson H, Kovats S, Ebi K, et al. The impact of extreme heat on morbidity in Milwaukee, Wisconsin. Climatic Change. 2012;110:959-76. ${ }^{17}$

\section{Disasters Due to Extreme Weather-Related Health Effects}

Higher temperatures evaporate soil moisture more quickly leading to severe droughts. But warm air can hold more moisture resulting in heavy precipitation, so that both floods and droughts are expected with projected extremes of the hydrologic cycle. Extreme weather events such as floods, 
droughts, and intense storms have claimed millions of lives during the past two decades, and affected many more physically, mentally, or through the loss of property or livelihoods. ${ }^{20}$

\section{Floods}

Floods are the most common natural weather disasters. ${ }^{21}$ In 2010, floods accounted for the highest number of victims (about 175 million people) out of all natural disasters globally. ${ }^{22}$ These losses mostly took place in mid- to low-income countries. ${ }^{23}$ For example, in Mozambique 285,000 people were affected in 2007 from flooding along the country's southern coast—causing 29 deaths and 140,000 people to be displaced from their homes. ${ }^{24}$ More than 80 percent of Mozambique's population is dependent on agriculture and most agriculture takes place in the country's extensive low-lying floodplains where the best soils are located. ${ }^{25,26}$ The regular flooding in these areas can rapidly overwhelm local coping capacities. ${ }^{27}$

While flooding often damages poorer countries more often, flooding is not unique to these countries. Severe, damaging floods recently hit Australia in 2010 and northeastern US in 2012. ${ }^{22-28}$ In the US, the amount of precipitation falling in the heaviest one percent of rain events increased by 20 percent in the past century, while total precipitation increased by seven percent. Over the last century, there was a 50 percent increase in the frequency of days with precipitation over four inches in the US upper Midwest. ${ }^{29}$ Other regions, notably the South, have also seen strong increases in heavy downpours, with most of these coming in the warm season and almost all of the increase coming in the last few decades.

\section{Hurricanes}

Records indicate that sea surface temperatures have steadily increased over the last 100 years, and more sharply over the last 35 years. The period from 1995-2004 recorded the highest average sea surface temperature on record and the sea surface temperatures off the northeast shelf of the US in 2012 were the highest recorded in 150 years..$^{30,31}$ These trends, in turn, have implications for hurricane occurrence and intensity. Hurricanes only form in regions where sea surface temperatures are above $26^{\circ} \mathrm{C}^{32}$ From 1995 to 2000 overall hurricane activity in the North Atlantic doubled and the Caribbean experienced a five-fold increase in activity. ${ }^{33}$ Hurricanes may become more frequent with continued warming and one study projects a near doubling in the frequency of category 4 and 5 storms by the end of the $21^{\text {st }}$ century. ${ }^{34}$ However, this frequency has been disputed. ${ }^{3}$ As well as occurring more often, hurricanes are likely to become more intense, as intensity is associated with warmer sea-surface temperatures..$^{35,36}$ 


\section{Wildfires}

Climate change is expected to increase the occurrence of wildfires, stemming from the combination of increased temperatures coupled with drought events. ${ }^{37}$ Wildfires produce large amounts of particulate matter and other toxic substances into the air stream. Fine particulate matter $\left(\mathrm{PM}_{25}\right)$ in the air adversely affects large numbers of people. ${ }^{38}$ For example, inhaling $\mathrm{PM}_{2.5}$ can exacerbate cardiac or respiratory problems (such as asthma and chronic obstructive pulmonary disease) in vulnerable people. A study on worldwide premature mortality estimated there were 339,000 premature deaths per year (range 260,000 to 600,000 ) that can be attributable to air pollution from forest fires. ${ }^{39}$

\section{Infectious Diseases}

Changes in temperature, humidity, rainfall, and sea level rise affect the incidence of food-, water- and vector-borne infectious diseases. Food- and water-borne diseases are expected, with confidence, to become a greater management problem as climate changes ${ }^{40}$ And, vector-borne diseases are an important aspect to the health impacts of climate change because of their widespread occurrence and sensitivity to climate factors. ${ }^{41-44}$ Examples include spread of water-borne and vector-borne diseases such as dengue, malaria, Chikungunya, West Nile Fever, Rift Valley Fever from their natural habitats to new locations via travelers and becoming endemic

\section{Water-borne diseases}

Reported water-borne disease outbreaks in the US from 1948-1994 were found to be related to months of heavy precipitation, compared to the 50 -year average precipitation for the watershed in which the outbreak occurred. ${ }^{45}$ There is credible evidence linking incidence of water-borne outbreaks from pathogens such as Cryptosporidium, Escherichia coli 0157:H7 and Campylobacter jejuni following heavy rains. ${ }^{46,47}$ Heavy rainfall and flooding can contaminate drinking or recreational water with pollution from sewage lines or agricultural fields. ${ }^{48,49}$ Storm events of greater than three inches $(7.5 \mathrm{cms})$ of rainfall within 24 hours can overwhelm combined sewer systems and lead to an overflow that contaminates recreational and drinking water sources ${ }^{50}$ For example, levels of $E$. coli in channels leading from Milwaukee, Wisconsin to Lake Michigan can be up to ten times higher in areas where there are no sewage overflows.

Climate change is anticipated to increase the frequency of these occurrences. Regional climate models, for example for the Great Lakes area 
of the US, show a 50 to 120 percent increase in sewage overflow events by the end of this century. ${ }^{50}$ This will pose increased hazards to drinking and recreational water quality. Global Climate Models (GCMs) that have been run for regional-level analysis predict_-with high certainty - that climate change will lead to heavier winter and spring precipitation in the state of Wisconsin. ${ }^{51}$ This projected precipitation pattern will have ramifications for cyanobacteria harmful algal blooms (HABs) in the Great Lakes region of the US. Elevated winter-spring rainfall and flushing events, followed by protracted periods of drought, has already been responsible for massive algal blooms in the Great Lakes ecosystem. ${ }^{52}$ In Peru, childhood diarrheal rates increased 200 percent during the 1997-1998 El Niño (sea warming) episode, likely due to higher survival time of diarrhea-causing pathogens, a greater demand for water and less conscientious hygiene practices. ${ }^{53}$ The worldwide average for diarrheal diseases in the future is projected to rise by 20 percent during the period 2040-2069 and by 29 percent for 2070-2099. ${ }^{54}$

\section{Food-borne diseases}

The relationship between food-borne outbreaks and temperature has been shown for several pathogens and in a variety of geographic settings. ${ }^{55-57}$ For example, D'Souza et al. (2004) showed that increased salmonellosis notifications in five Australian cities were related to a rise in the mean temperature in the previous month. ${ }^{58}$ Heat contributed to an estimated 30 percent of cases of salmonellosis in much of continental Europe, especially when temperatures exceeded a threshold of six degrees Celsius above average.$^{59}$ A recent re-evaluation of food-borne illness over time in England and Wales showed a strong confirmed correlation with temperature in the current and previous week. The study discusses the importance of lowering pathogen loads in livestock through vaccinations of chicken flocks, limits on antibiotic use in cattle to retard development of resistant strains, and improvement of hygiene practices in abattoirs as methods to help curtail food-borne outbreaks. ${ }^{57}$

\section{Vector-borne diseases}

Vector-borne diseases most often refer to infections transmitted by the bite of infected insects such as mosquitoes or ticks. Because of their vast occurrence and sensitivity to climate factors, vector-borne diseases are frequently modeled as they will likely shift in spatial or temporal distribution due to climate change. In developing countries, there is high occurrence and mortality from vector-borne diseases. The impacts in developing countries could therefore be very dramatic. For example, the vector-borne disease, 
malaria, is transmitted between individuals by Anopheline mosquitoes who carry the plasmodium parasite. Malaria is currently present in 101 countries, and 40 percent of the world's population live in areas with malaria. ${ }^{60}$ Malaria claimed 655,000 deaths in 2010 out of an estimated 216 million episodes worldwide. ${ }^{61}$ Most malarial deaths are in children under five years in the Africa Region.

Malaria parasite development is associated with climate change because it is sensitive to climate fluctuations, such as changes in temperature. ${ }^{62}$ Climate change plays an important role in the exacerbation of malaria in particular regions, such as eastern Africa were modest warming can drive large increases in malaria transmission. ${ }^{63}$ While modest warming can drive large increases in transmission, if conditions are otherwise suitable, variations around the maximum temperature tend to slow malaria parasite development down. In addition to temperature variations, heavy rains can also increase Anopheline mosquito breeding and parasite development. Overall, climate change is associated with the impact of malaria control programs, but malaria is likely to have declined. ${ }^{64}$

Dengue and other vector-borne diseases such as Chikungunya are spreading from tropical to temperate climate areas.$^{65}$ Chikungunya-which originally emerged in Tanzania and then re-emerged in southeast Asia, the Indian Ocean islands, Indian subcontinent, the Caribbean and Africa-is a mosquito borne disease that causes fever, rash and long-term debilitating joint pain. Chikungunya is projected to have climate suitability for transmission in the first half of the $21^{\text {st }}$ century in Western Europe, and in central parts of Europe from mid-century onward. ${ }^{66-68}$ The highest risk of Chikungunya is projected for east-central Europe by the end of the 21st century ${ }^{68}$

\section{Malnutrition and Food Insecurity}

More than 800 million people are estimated to be suffering from chronic hunger. ${ }^{69}$ According to the IPCC, the global risk to food security becomes very severe under an increase of four to six degrees Celsius or higher global mean temperature. ${ }^{1}$

There is concern that climate change will continue to adversely affect nutrition because of increased drought conditions and crop failures, particularly in Africa. In developing countries, where millions of people are malnourished, climate changes that affect crop yields can be devastating. Of particular concern are children who experience undernourishment, stunting, and malnutrition-related deaths. A recent study projected 108,028 malnutrition-related childhood deaths from climate change in $2030 .{ }^{70}$ 
Climate change effects on global agricultural productivity will vary regionally, with reductions especially in sub-Saharan Africa and south Asia. ${ }^{71}$ Estimates are that by the 2050 s, climate change would increase the percentage at risk of hunger from a current 34 percent to a level of 64 to 72 percent, unadjusted for potential adaptive interventions. Nelson et al. (2009) found that by 2050 yields of staple crops would decline in developing countries and that child underweight would be approximately 20 percent higher, equivalent to approximately 25 million children being affected. ${ }^{72}$ In Kenya, a country dependent on rain-fed agriculture, projected changes in temperature and precipitation are expected to compromise agriculture yields with subsequent increases in stunting of children. ${ }^{73}$

\section{Mental Health}

Disasters such as tornadoes, floods, hurricanes, heat waves, and droughts can have significant adverse mental health impacts on people. Disasters can bring about or worsen anxiety, depression, aggression and other mental illnesses. For example, droughts can cause chronic psychological distress, a loss of hope, and an increased incidence of suicide. ${ }^{74,75}$ Also, increases in temperatures can bring about self-harm, violence, increased accidents, and suicide, ${ }^{76-78}$ all serious risks to public health. Both mitigation and adaptation strategies are necessary to decrease climate change impacts on mental health.

\section{Vulnerable Populations}

Climate change adversely impacts human health. However, certain vulnerable populations are at highest risk. Vulnerable people include the elderly, children, pregnant women, individuals with predisposing health conditions, low-income groups, and women. ${ }^{79-84}$ However, a recent study suggests that adverse climate events have not affected the health and wellbeing of women in Australia, ${ }^{85}$ and that the vulnerability of men and women varies by region. Individuals who are physically active, outdoor workers, and indoor workers with minimal access to cooling systems while working are also vulnerable to the extreme heat of climate change. ${ }^{4}$

In addition to vulnerable people, there are also places that are particularly vulnerable to climate change impacts, ${ }^{86}$ because location has an important influence on the potential for losses caused by climate change. ${ }^{87}$ These include:

- Areas or populations within or bordering regions with a high endemicity of climate-sensitive diseases, for example, regions in Africa with high prevalence of malaria $;^{3}$

- Areas at risk from combined climate impacts relevant to health, for example, stress on food and water supplies or risk of coastal flooding; ${ }^{3}$ 
- Inland cities at mid- and low latitudes, where present-day temperatures are frequently close to the tolerable maximum; ${ }^{6}$

- Areas with an observed association between epidemic disease and weather extremes, for example, El Niño-linked epidemics; ${ }^{3}$ and

- Areas at risk from concurrent environmental or socioeconomic stresses, for example, local stresses from land-use practices or an impoverished or undeveloped health infrastructure with little capacity to adapt. ${ }^{3}$

Additionally, changes in seasonal river flows, increases in floods and droughts, decreased food security and biodiversity loss can increase as temperatures rise. For example, areas in Africa that are sensitive to droughts and surges in malaria, have poor health-infrastructures, low socioeconomic status, and are reliant on subsistence farming. This creates significant vulnerability to the impacts of a warming climate. Low-lying coastal regions, delta regions, and arid regions are also at special risk as the global climate warms..$^{88}$

Another vulnerable group includes individuals in rural Australia. A severe drought in Australia has been linked to psychological distress and to food insecurity for those residing in rural and remote areas ${ }^{89}$ Psychological distress can lead to suicides, and food insecurity can lead to economic losses and malnourishment.

\section{ETHICAL ASPECTS OF CLIMATE CHANGE AND HEALTH}

Climate change raises important ethical concerns in several ways. First, on a global scale, the nations with the highest prevalence of climate-sensitive diseases (e.g., malnutrition, diarrhea and vector-borne diseases) are the least responsible for carbon emissions that to date are causing today's climate change..$^{90}$ Large populations of the global south have a very low per capita emission rates, although total emissions from developing nations are growing rapidly, and China surpassed the US in 2006. The US, with five percent of the global population, produces 25 percent of total annual greenhouse gas emissions. This discrepancy exemplifies the ethical implications posed by climate change on a global scale, shown graphically in the figure below. Poor populations in the developing world have little by way of industry, transportation, or intensive agriculture, they contribute only a fraction of the greenhouse gases per capita that the developed countries produce, and their capacity to protect themselves against the adverse consequences of what are mostly wealthy populations' greenhouse gases is quite limited. If developing nations do not choose development pathways that use more efficient energy technology than highly industrialized 
countries have employed so far in its developmental history, global climate change trends will intensify. ${ }^{91}$ Intensifying trends of global climate change will impact poor populations, at the benefit of development. Arriving at a balance between development and mitigating climate change is imperative.
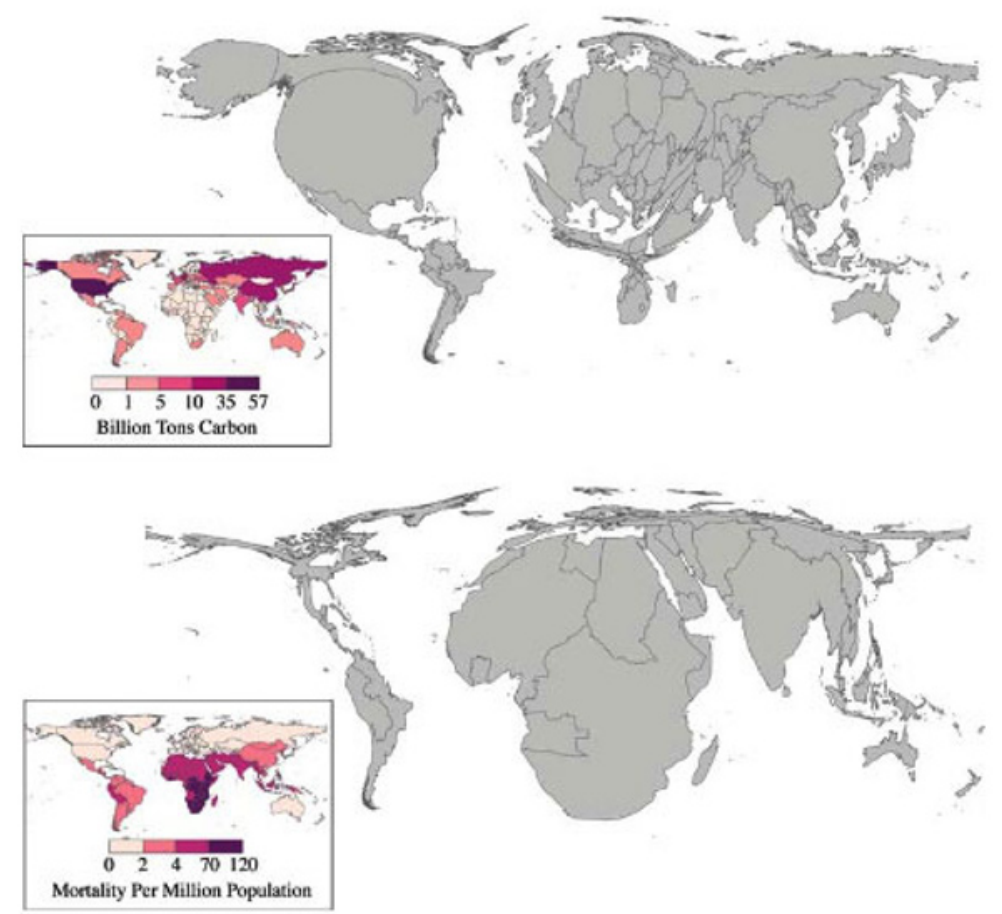

Fig. 2. The above cartogram shows two different maps revealing the growing ethical crisis of climate change. The top map of the globe shows conflations and deflations of geographical areas of the globe according to carbon dioxide emissions. For example, countries like the US are much larger than usual, and some countries like Africa are much smaller than their normal geographical size-revealing the discrepancy of varying carbon dioxide $\left(\mathrm{CO}_{2}\right)$ emissions globally. The lower map shows mortality in populations worldwide due to four climate-sensitive health effects (malaria, malnutrition, diarrhea, and inland flood-related fatalities). As shown, some nations that are least responsible for $\mathrm{CO}_{2}$ emissions are not experiencing some of the greatest health impacts of climate change. Countries like Africa are disproportionally impacted by climate-sensitive health effects, whereas countries like the US have much less of an impact, hence the shrunken geographic size of the US in the lower geographical map.

Source: Patz JA, Gibbs HK, Foley JA, Rogers JV, Smith KR. Climate change and global health: quantifying a growing ethical crisis. Eco Health. 2007;4:397-405..$^{90}$ 
This balance between the benefits of development and the costs of climate change among vulnerable populations and countries is also an issue intergenerationally. Greenhouse gases have long residence lifetimes in the atmosphere. Carbon dioxide can last in the atmosphere for hundreds of years, and hydrofluorocarbons can last in the atmosphere for thousands of years. ${ }^{1}$ This means that the impacts of climate change today are from emissions well into the past, and that emissions today will have an impact on future generations.

At present, the atmosphere is concentrated with 400 ppm $\mathrm{CO}_{2}$ eq. ${ }^{92}$ Before the Industrial Revolution, during the 1700 s to 1800 s, the atmosphere contained 280 ppm. $^{92}$ Science shows that exceeding $450 \mathrm{ppm}$ will be disruptive for future generations. ${ }^{92}$ Is it fair for future generations to be harmed by the impacts of climate change at the benefit of development when the current generation is aware of the harm our emissions will produce? Which countries and its people should have priority to the remaining $50 \mathrm{ppm}$ if countries agree to stay within safe limits of greenhouse gas emissions? These are very important ethical questions that address the intergenerational issue of climate change.

Regarding the first question, notable climate economists, Nicholas Stern and William Nordhaus, have disputed one another on how much value we should place on the future costs of climate change. Nicholas Stern uses a 1.4 percent discount rate in his economic analyses of climate change, while William Nordhaus applies a 6 percent discount rate. ${ }^{93,94}$ A six percent discount rate is more reflective of the actual market; how people are buying and selling for goods and services, their willingness to pay, their investments, savings, and spending. However, people's behavior in the market might not be reflective of people's willingness to pay to mitigate climate change. A six percent discount rate recommends to policymakers that the current generation spend less money on mitigating climate change, whereas a 1.4 percent discount rate recommends more spending on mitigating climate change. Ultimately, agreeing on how much money the current generation should be spending to mitigate climate change for the benefit of future people is a contentious ethical issue.

\section{CO-BENEFITS OF MITIGATION}

One element missing from decisions on mitigation is that of "co-benefits"that is, immediate side-benefits that ensue from greenhouse mitigation actions targeted to reduce future climate change. Numerous health co-benefits are among those arising from a reduction in fossil fuel combustion. ${ }^{95-99}$ There 
are different types of co-benefits that mitigation efforts can achieve. ${ }^{97,100}$ One way co-benefits of mitigation can be achieved is through policies and technologies that result in more efficient energy production and reduced energy demand. Sustainable energy sources such as wind and solar energy do not contribute to greenhouse gas emissions.

Health is improved when emissions are decreased, such as $\mathrm{PM}_{2.5}$ (discussed above), which are harmful mainly to urban populations, and also to rural populations using biomass for cooking. ${ }^{101}$ Also, less fossil fuelintensive development can offer the benefit of reducing food- and waterborne related morbidity, for example, by 16 to 28 percent under lowest emissions trajectory. ${ }^{102}$ This is because fossil fuel-intensive development contributes to climate change, which increases temperatures, rainfall, flooding and humidity. As discussed above, increasing temperatures and rainfall coupled with humidity, for example, can increase diarrheal incidence and diarrhea morbidity. ${ }^{52,103}$ Increases in temperature can increase the replication and survival of diarrhea-causing bacteria, protozoa, and foodborne microorganisms. ${ }^{104}$ Thus, decreasing fossil fuel use in development, can reduce food- and water-borne related morbidity.

Transportation policies that rely on walking, bicycling, mass transit, and fuel-efficient automobiles result in less greenhouse gas emissions than are currently produced by increased reliance on fuel-inefficient automobiles or vehicles without internal combustion engines for most transportation. Increasing green-spaces in cities can increase cool spaces (i.e., shaded areas) and social connectivity. ${ }^{105}$ Increasing availability for "active transport" (via walking or bicycling) in cities is both beneficial for health and contributes to the reduction of greenhouse gas emissions. Urban design strategies can reduce emissions, while at the same time benefit health by reducing obesity, cardiovascular disease diabetes, and mental health through increased physical activity. For example, one study from the US showed that cities with the highest rates of commuting by bike or by walking have obesity and diabetes rates 20 and 23 percent lower, respectively, than cities with the lowest rates of active commuting. ${ }^{106}$ According to a study by Grabow et al. (2011) adopting a greener transportation system of more biking and walking, and less automobile trips, in the upper Midwest of the US alone, could save 1,300 lives and $\$ 8$ billion in avoided mortality and health costs per year from improving air quality and physical fitness. ${ }^{107}$

Shindell et al. (2012) addressed the tropospheric ozone and black carbon (BC) contribution to both degraded air quality and global warming. ${ }^{99}$ The authors identified 14 best interventions targeting methane and $\mathrm{BC}$ emissions that reduce projected global mean warming approximately 0.5 degrees Celsius by 2050. The resulting "co-benefit" was the avoidance of 
0.7 to 4.7 million annual premature deaths from outdoor air pollution and increased annual crop yields by 30 to 135 million metric tons due to ozone reductions in 2030 and beyond (see figure below). The valuation was dominated by health effects from reduced BC in the air. While this study was global in nature, the findings apply to any location with coal-fired power plants, the most substantial contributor to black carbon particulates.

Another contributor to resource consumption and emissions of greenhouse gases is population growth. A recent study found that $\mathrm{CO}_{2}$ emissions could be lowered by 30 percent in 2100 if access to contraception was provided to women expressing a need for it. ${ }^{19}$ Access to reproductive health services could slow population growth and thus resource consumption and emissions, and improve maternal and child health. Access to reproductive health services and family planning saves women's lives by reducing maternal mortality in the highest risk age groups (youngest and oldest women $)^{108}$ and by reducing the total number of births in these highrisk groups. ${ }^{109}$

Co-benefits of mitigation are especially attractive, cost-effective, and politically feasible. However, in planning solutions such as sustainable communities or family planning services, it is essential that affected communities be involved. Poor communities and communities of color bear a disproportionate burden from many environmental health threats. These groups must be included in planning equitable solutions to avoid the potential for widening the already large gap in the access to health services and healthy, desirable neighborhoods. New health services and communities must be designed with cultural sensitivity and diversity in mind so that all people can be afforded a realistic chance to new health opportunities, and so that environmental justice issues are considered at every level.

\section{ADAPTATION}

Adaptation (or preparedness) refers to efforts to reduce the public health impact of climate change, that based on the inertia of our global climate system, will inevitably be required regardless of the extent of greenhouse gas mitigation efforts. Many of today's current challenges, such as deaths from heat waves, floods, and air pollution will be exacerbated by climate change due to past emissions. It is important that populations are prepared for more extreme adverse weather events, but at the same time, adaptation efforts must not supplant parallel strategies for mitigation targeting the root cause of climate change. 
Examples of adaptation measures include: the construction of seawalls, genetically modified crops that will better withstand heat and droughts, and migration of island people from their homes. Adaptation can build from analyses of the strengths and weaknesses of current prevention efforts, and a rethinking of potential thresholds that may change in the future (e.g., expected change in the volume of storm water runoff, or the frequency of heat waves). ${ }^{3}$ This analysis and rethinking requires focusing on improvements in basic public health functions, such as enhancing disease surveillance, monitoring risky exposures, and managing communication between health and other sectors to address changes in disease incidence and geographic range. ${ }^{110}$

There are particular climate change health impacts that are susceptible to adaptation. These include some infectious diseases, health impacts from extreme weather events, and impacts from rising sea levels. When basic public health and health care services are improved, these services are better equipped to detect and prevent disease outbreaks, and to respond to life threatening extreme weather events. For example, early warning systems that detect heat waves can forecast weather conditions and predict possible health outcomes, while activating effective and timely response plans. ${ }^{111}$

On the other hand, mental health-related illnesses are less likely to improve from adaptation planning. For example, if a group of people that migrate from their home are physically benefited by this migration, they may still suffer from anxiety, depression and other mental illnesses due to displacement. Migration as an adaptation strategy can have deleterious effects on health, in addition to mental illness. ${ }^{112,113}$ For example, within the Pacific region, there has been migration from outer islands to urban areas. Some migrants have been infected with disease from crowding, with lack of adequate water supplies, waste disposal and poor housing. ${ }^{115}$ These people suffer from higher blood pressure and an increase in cigarette smoking. Where large numbers of people are forced to migrate simultaneously, there could be considerable cultural, social, economic and health implications for receiving communities, particularly where these peoples may be distressed. ${ }^{114}$

When policymakers and public health professionals are considering which adaptation efforts to make, it is important to weigh the potential benefits and risks. Some adaptation efforts may have unintended repercussions to the environment and human health, while others can achieve protection from climate change threats without significant side effects. 


\section{CONCLUSION}

The health impacts of climate change are serious especially for vulnerable population groups and nations. Mitigation strategies that will reduce greenhouse gas emissions are essential for a reduction in climate change impacts and for many other benefits for human health and the environment. Given the current and future impacts from climate change due to greenhouse gas emissions and their long atmospheric residence time, some adaptation is critical for climate policy strategies. Global policies to reduce the key factors in global climate change are a vital moral duty to protect the current and future generations. Such protection requires mitigating the dangers of climate change as much as possible and aiding those who will be most harmed. This coupled with more immediately realized co-benefits of improved air quality and opportunities for physical fitness, there is a very strong rationale to create a low-carbon economy as soon as possible.

Conflicts of Interest: None declared.

\section{REFERENCES}

1. Climate Change 2013 - The Physical Science Basis: Working Group I Contribution to the Fifth Assessment Report of the Intergovernmental Panel on Climate Change. New York (NY): Cambridge University Press; 2014. Available from URL: http://www.climatechange2013.org/images/report/WG1AR5_Front matter_FINAL.pdf (Accessed 9 July 2014).

2. Haines AP, Patz, JA. Health effect of climate change. American Medical Association. JAMA. 2004;291:99-103.

3. Patz JA. Climate change. In: Frumkin H, (editor). Environmental Health: From Global to Local. (2nd Edition). San Francisco (CA): John Wiley \& Sons Inc; 2010.

4. Hanna EG, Kjellstrom T, Bennett C, Dear K. Climate change and rising heat: population health implications for working people in Australia. Asia Pac J Public Health. 2011;23:S14-26.

5. Maloney S, Forbes $\mathrm{C}$. What effect will a few degrees of climate change have on human heat balance? Implications for human activity. Int J Biometeorol. 2011;55:147-60.

6. Kjellstrom TB, Lemke, Otto M. Mapping occupational heat exposure and effects in South-East Asia: ongoing time trends 1980-2009 and future estimates to 2050. Ind Health. 2013;51:56-67.

7. Kjellstrom TI, Holmer, Lemke B. Workplace heat stress, health and productivity - an increasing challenge for low and middle-income countries during climate change. Glob Health Action. 2009;2. 
8. Centers for Disease Control and Prevention. Heat-related deaths after an extreme heat event — four states, 2012, and United States, 1999-2009. MMWR Wkly. 2013;62:433-6.

9. Anderson GB, Bell ML. Heat waves in the United States: mortality risk during heat waves and effect modification by heat wave characteristics in 43 U.S. communities. Environ Health Perspect. 2011;119:210-8.

10. Rocklov JK, Ebi K, Forsberg B. Mortality related to temperature and persistent extreme temperatures: a study of cause-specific and age-stratified mortality. Occup Environ Med. 201;68:531-6.

11. Semenza JC, Rubin CH, Falter KH, Selanikio JD, Flanders WD, et al. Heatrelated deaths during the July 1995 heat wave in Chicago. N Engl J Med. 1996;335:84-90.

12. Robine JM, Cheung SL, LeRoy S, Van Oyen H, Herrman FR. Report on excess mortality in Europe during summer 2003. EU Community Action Programme for Public Health, Grant Agreement 2005. February 2007.

13. Brucker G. Vulnerable populations: Lessons learnt from the summer 2003 heat waves in Europe. Eurosurveillance. 2005;10:146.

14. Kosatsky T. The 2003 European Heat Waves. Eurosurveillance. 2005;10:147.

15. Hayhoe K, Sheridan S, Kalkstein L, Greene S. Climate change, health waves, and mortality projections. J Great Lakes Research. 2010;36:65-73.

16. Peng, RD, Bobb JF, Tebaldi C, McDaniel L, Bell ML, Dominici F. Toward a quantitative estimate of future heat wave mortality under global climate change. Environ Health Perspect. 2011;119:701-6.

17. Li B, Sain S, Mearns L, Anderson H, Kovats S, et al. The impact of extreme heat on morbidity in Milwaukee, Wisconsin. Climatic Change. 2012;110:959-76.

18. Hajat S, O'Connor M, Kostasky T. Health effects of hot weather: from awareness of risk factors to effective health protection. Lancet. 2010;375:856-63.

19. O’Neill MS, Jackman DK, Wyman M, Manarolla X, Gronlund CJ, et al. US local action on heat and health: are we prepared for climate change? Int $\mathrm{J}$ Public Health. 2010;55:105-12.

20. International Federation of Red Cross Red Crescent Societies. World disaster report 1998. New York (NY): Oxford University Press; 1998.

21. Intergovernmental Panel on Climate Change (IPCC). Fourth Assessment Report: Climate Change 2007 (AR4). Working Group II Report. Impacts, adaptation and vulnerability. New York (NY): Cambridge University Press; 2007.

22. Guha-Sapir D, Vos F, Below R. Annual disaster statistical review 2010 The numbers and trends. Brussels: Center for Research on the Epidemiology of Disasters; 2011(1-50).

23. Dar OA, Khan MS, Murray V. Conducting rapid health needs assessments in the cluster era: experience from the Pakistan flood. Prehosp Disaster Med. 2011;03:212-6.

24. The World Bank. Disaster risk management programs for priority countries 2nd edition. Washington (DC): World Bank; 2011. 
25. United Nations International Strategy for Disaster Reduction (UNISDR) and The World Bank. Disaster risk management programs for priority countries: summary. Washington, (DC): Global Facility for Disaster Reduction and Recovery; 2008.

26. Arnall A, Thomas D, Twyman C, Liverman D. Flooding, resettlement, and change in livelihoods: evidence from rural Mozambique. Disasters. 2013;37: 468-88.

27. Brouwer R, Nhassengo J. About bridges and bonds: community responses to the 2000 floods in Mabalane Mozambique district. Disasters. 2006;30:234-55.

28. Powell T. Hanfling D, Gostin LO. Emergency preparedness and public health: the lessons of hurricane Sandy. JAMA. 2012;308:2569.

29. Kunkel KE, Easterline DR, Redmond K, Hubbard K. Temporal variations of extreme precipitation events in the United States: 1895-2000. Geophys Res Lett. 2003;30.

30. Trenberth K. Uncertainty in hurricanes and global warming. Science. 2005;308: 1753-4.

31. National Oceanic and Atmospheric Administration. (NOAA). Sea surface temperatures reach highest level in 150 years on Northeast Continental Shelf. NOAA Northeast Fisheries Science Center. Advisory 2013-No. 1, 25 April 2013, SS13.04.

32. Gray, WM. Hurricanes: Their formation, structure and likely role in the tropical circulation. In: Shaw DB, (editor). Meteorology over the Tropical Oceans. London: Royal Meteorology Society; 1979.

33. Goldenberg SB, Landsea CW, Mestas-Nuñez AM, Gray WM. The recent increase in Atlantic hurricane activity: causes and implications. Science. 2001;293:474-9.

34. Bender MA, Knutson TR, Tuleya RE, Sirutis JJ, Vecchi GA, et al. Modeled impact of anthropogenic warming on the frequency of intense Atlantic hurricanes. Science. 2010;327:454-8.

35. Webster PJ, Holland GJ, Curry JA, Chang HR. Changes in tropical cyclone number, duration, and intensity in a warming environment. Science. 2005; 309:1844-6.

36. Emanuel K, Sundararajan R, Williams J. Hurricanes and global warming: results from downscaling IPCC AR4 simulations. Bull Amer Meteor Soc. 2008;89:347-67.

37. Handmer JY, Honda ZW, Kundzewicz N, Arnell G, Benito J, et al. Changes in impacts of climate extremes: human systems and ecosystems. In: Field CB, et al. (editors). Managing the Risks of Extreme Events and Disasters to Advance Climate Change Adaptation. A Special Report of Working Groups I and II of the Intergovernmental Panel on Climate Change. New York (NY): Cambridge University Press; 2012. p.231-90.

38. Finlay SE, Moffat A, Gazzard R, Baker D, Murray V. Health impacts of wildfires. PLoS Curr. 2012;4:e4f959951cce2c. 
39. Johnston FH, Henderson SB, Chen Y, Randerson JT, Marlier M, et al. Estimated global mortality attributable to smoke from landscape fires. Environ Health Perspect. 2012;120:695-701.

40. Patz JA, Hahn MB. Climate change and human health: A one health approach. Curr Top Microbiol Immunol. 2013;366:141-71.

41. Bangs MJ, Larasati RP, Corwin AL, Wuryadi S. Climatic factors associated with epidemic dengue in Palembang, Indonesia: implications of short-term meteorological events on virus transmission. Southeast Asian J Trop Med Public Health. 2006;37:1103-16.

42. Bi P, Zhang Y, Parton KA. Weather variables and Japanese encephalitis in the metropolitan area of Jinan city, China. J Infect. 2007;55:551-6.

43. Halide H, Ridd P. A predictive model for Dengue hemorrhagic fever epidemics. Int J Environ Health Res. 2008;18:253-65.

44. Wu PC, Lay JG, Guo HR, Lin CY, Lung SC, Su HJ. Higher temperature and urbanization affect the spatial patterns of dengue fever transmission in subtropical Taiwan. Sci Total Environ. 2009;407:2224-33.

45. Curriero FC, Patz JA, Rose JB, Lele S. The Association between extreme precipitation and waterborne disease outbreaks in the United States, 19481994. Am J Public Health. 2001;91:1194-9.

46. MacKenzie WR, Hoxie NJ, Proctor ME, Gradus MS, Blair KA, et al. A massive outbreak in Milwaukee of cryptosporidium infection transmitted through the public water supply. New Engl J Med. 1994;331:161-7.

47. Hrudey SE, Payment P, Huck PM, Gillham RW, Hrudey EJ. A fatal waterborne disease epidemic in Walkerton, Ontario: comparison with other waterborne outbreaks in the developed world. Water Sci Technol. 2003;47:7-14.

48. Lipp EK, Kurz R, Vincent R, Rodriguez-Palacios C, Farrah SR, Rose JB. The effects of seasonal variability and weather on microbial fecal pollution and enteric pathogens in a subtropical estuary. Estuaries. 2001;24:266-76.

49. Thomas KM, Charron DF, Waltner-Toews D, Schuster C, Maarouf AR, Holt JD. A role of high impact weather events in waterborne disease outbreaks in Canada, 1975 - 2001. Int J Environ Health Res.2006;16:167-80.

50. Patz JA, Vavrus SJ, Uejio CK, McLellan SL. Climate change and waterborne disease risk in the Great Lakes region of the U.S. Am J Preventive Med. 2008;35:451-8.

51. Vavrus S, Van Dorn J. Projected future temperature and precipitation extremes in Chicago. J. Great Lakes Res. 2010;36:1-6.

52. Paerl HW, Paul VJ. Climate change: links to global expansion of harmful cyanobacteria. Water Res. 2012;46:1349-63.

53. Checkley W, Epstein LD, Gilman RH, Figueroa D, Cama RI, et al. Effect of El Niño and ambient temperature on hospital admissions for diarrhoeal diseases in Peruvian children. Lancet. 2000;355:442-50.

54. Kolstad EW, Johansson KA. Uncertainties associated with quantifying climate change impacts on human health: A case study for diarrhea. Environ Health Perspect. 2011;119:299-305. 
55. Zhang Y, Bi P, Hiller JE, Sun Y, Ryan P. Climate variations and bacillary dysentery in northern and southern cities of China. J Infect. 2007;55:194-200.

56. Bentham G, Langford IH. Environmental temperatures and the incidence of food poisoning in England and Wales. Int J Biometeorol. 2001;45:22-6.

57. Lake IR, Gillespie IA, Bentham G, Nichols GL, Lane C, et al. A re-evaluation of the impact of temperature and climate change on foodborne illness. Epidemiol Infect. 2009;137:1538-47.

58. D’Souza RM, Becker NG, Hall G, Moodie KB. Does ambient temperature affect foodborne disease? Epidemiology. 2004;15:86-92.

59. Kovats RS, Edwards SJ, Hajat S, Armstrong BG, Ebi KL, Menne B. The effect of temperature on food poisoning: a time-series analysis of salmonellosis in ten European countries. Epidemiol Infect. 2004;132:443-53.

60. Greenwood B, Mutabingwa T. Malaria in 2002. Nature. 2002;415:670-2.

61. World Health Organization. World Malaria Report 2011 - Summary and Key Points. 2011. Available from URL: http://www.who.int/malaria/world_malaria_ report_2011/wmr2011_summary_keypoints.pdf (Accessed 9 July 2014).

62. Paaijmans, KP, Blanford S, Bell AS, Blanford JI, Read AF, Thomas MB. Influence of climate on malaria transmission depends on daily temperature variation. Proc Natl Acad Sci. 2010;107:15135-9.

63. Alonso D, MJ Bouma, Pascual M. Epidemic malaria and warmer temperatures in recent decades in an East African highland. Proc Biol Sci. 2011;278:1661-9.

64. Gething PW, Smith DL, Patil AP, Tatem AJ, Snow RW, Hay SI. Climate change and the global malaria recession. Nature. 2010;465:342-5.

65. Schlipkoter U, Flahault A. Communicable diseases: achievements and challenges for public health. Public Health Rev. 2010;32:90-119.

66. Pialoux G, Gauzere BA, Jaureguiberry S, Strobel M. Chikungunya, an epidemic arbovirosis. Lancet Infect Dis. 2007;7:319-27.

67. Burt FJ, Rolpf MS, Rulli NF, Mahalingam S, Heise MT. Chikungunya: a reemerging virus. Lancet. 2012;379:662-71.

68. Fischer D, Thomas SM, Suk JE, Sudre B, Hess A, et al. Climate change effects on Chikungunya transmission in Europe: geospatial analysis of vector's climatic suitability and virus' temperature requirements. Int J Health Geog. 2013;12(51).

69. Food and Agriculture Organization, , IFAD and WFP. The state of food insecurity in the world 2013: The multiple dimensions of food security. Rome: FAO; 2013.

70. Lloyd SJ, Kovats RS, Chalabi Z. Climate change, crop yields, and malnutrition: development of a model to quantify the impact of climate scenarios on child malnutrition. Environ Health Perspect. 2011;119:1817-23.

71. Battisti DS, Naylor RL. Historical warnings of future food insecurity with unprecedented seasonal heat. Science. 2009;323:240-4.

72. Nelson GC, Rosegrant MW, Koo J, Robertson R, Sulser T, et al. Climate change: impact on agriculture and costs of adaptation. Updated 2009. Washington, (DC): International Food Policy Research Institute; 2009. 
73. Grace K, Davenport K, Funk C, Lerner AM. Child malnutrition and climate in Sub-Saharan Africa: An analysis of recent trends in Kenya. Applied Geography. 2012;35:405-13.

74. Hanigan IC, Butler CD, Kokic PN, Hutchinson MF. Suicide and drought in New South Wales, Australia, 1970-2007. Proc Natl Acad Sci U S A. 2012;109: 13950-5.

75. Berry HL, Hogan A, Owen J, Rickwood DJ, Fragar L. Climate change and farmers' mental health: risks and responses. Asia Pac J Public Health. 2011; 23:119-32.

76. Li T, Horton R, Kinney P. Projecting temperature-related mortality impacts in New York City under a changing climate. Epidemiology. 2011;22:S15.

77. Nitschke M, Tucker GR, Bi P. Morbidity and mortality during heatwaves in metropolitan Adelaide. Med J Aust. 2007;187:662-5.

78. Page LA, Hajat S, Kovats RS. Relationship between daily suicide counts and temperature in England and Wales. Br J Psychiatry. 2007;191:106-12.

79. Perera FP. Children are likely to suffer most from our fossil fuel addiction. Environ Health Perspect. 2008;116:987-90.

80. Yu W, Vaneckova P, Mengersen K, Pan X, Tong S. Is the association between temperature and mortality modified by age, gender and socio-economic status? Sci Total Environ. 2010;408:3513-8.

81. Strand LB, Barnett AG, Tong S. Maternal exposure to ambient temperature and the risks of preterm birth and stillbirth in Brisbane, Australia. Am J Epidemiol. 2012;175;99-107.

82. Jamieson DJ, Theiler RN, Rasmussen SA. Emerging infections and pregnancy. Emerg Infect Dis. 2006;12:1638-43.

83. Peduzzi P, Chatenoux B, Dao H, De Bono A, Herold C, et al. Global trends in tropical cyclone risk. Nature Climate Change. 2012;2:289-94.

84. Tawatsupa B, Lim LL, Kjellstrom T, Seubsman SA, Sleigh A, and the Thai Cohort Study Team. The association between overall health, psychological distress, and occupational heat stress among a large national cohort of 40,913 Thai workers. Glob Health Action. 2010;3:10.3402/gha.v3i0.5034.

85. Powers JR, Loxton D, Baker J, Rich JL, Dobson, AJ. Empirical evidence suggests adverse climate events have not affected Australian women's health and well-being. Aust N Z J Public Health. 2012;36:452-7.

86. Hess JJ, Malilay JN, Parkinson AJ. Climate change: the importance of place. Am J PrevMed. 2008;35:468-78.

87. Samson J, Berteaux D, McGill MJ, Humphries MM. Geographic disparities and moral hazards in the predicted impacts of climate change on human populations. Global Ecology Biogeography. 2011;20:532-44.

88. McCarthy J, Canziani OF, Leary NA, Dokken DJ, White KS (editors). Climate change 2001: impacts, adaptation, and vulnerability. Contribution of Working Group II to the Third assessment report of the Intergovernmental Panel on Climate Change. Intergovernmental Panel on Climate Change. New York (NY): Cambridge University Press; 2001. 
89. Berry HL, Butler JR, Burgess CP, King UG, Tsey K, et al. Mind, body, spirit: co-benefits for mental health from climate change adaptation and caring for country in remote Australian Aboriginal communities. N S W Public Health Bull. 2010;21:139-45.

90. Patz JA, Gibbs HK, Foley JA, Rogers JV, Smith KR. Climate change and global health: quantifying a growing ethical crisis. Eco Health. 2007;4:397-405.

91. Patz JA, Kovats RS. Hotspots in climate change and human health. BMJ. 2002;325:1094-8.

92. Intergovernmental Panel on Climate Change (IPCC) Fourth assessment report: climate change 2007 (AR4).

93. Stern N. The Economics of Climate Change: The Stern Review. Cambridge and New York (NY): Cambridge University Press; 2007.

94. Broome J. The ethics of climate change. Scientific American 2008;298:96-102.

95. Haines A, McMichael AJ, Smith KR, Roberts I, Woodcock J, et al. Public health benefits of strategies to reduce greenhouse-gas emissions: overview and implications for policy makers. Lancet. 2009;374:2104-14.

96. ApSimon H, Amann M, Astroem S, Oxley T. Synergies in addressing air quality and climate change. Climate Policy. 2009;9:669-80.

97. Smith KR, Balakrishnan K. Mitigating climate, meeting MDGs, and moderating chronic disease: the health co-benefits landscape. In: Commonwealth Health Ministers' Update 2009. London: Commonwealth Secretariat; 2009. p. 59-65.

98. United Nations Environment Programme (UNEP). Integrated assessment of black carbon and tropospheric ozone. Nairobi, Kenya: UNEP; 2011.

99. Shindell DJ, Kuylenstierna JCI, Vignati E, Van Dingenen R, Amann M, et al. Simultaneously mitigating near-term climate change and improving human health and food security. Science. 2012;335:183-9.

100. Smith KR, Jerrett M, Anderson HR, Burnett RT, Stone V, et al. Public health benefits of strategies to reduce greenhouse-gas emissions: health implications of short-lived greenhouse pollutants. Lancet. 2009;374:2091-103.

101. Smith KR, Dutta K, Chengappa C, Gusain PPS, Masera O, et al. Monitoring and evaluation of improved biomass cookstove programs for indoor air quality and stove performance: conclusions from the Household Energy and Health Project. Energy for Sustainable Development. 2007;11:5-18.

102. El-Fadel M, Ghanimeh S, Maroun R, Alameddine I. Climate change and temperature rise: implications on food- and water-borne diseases. Sci Total Enviro. 2012;437:15-21.

103. Chou WC, Wu JL, Wang YC, Huang H, Sung FC, Chuang CY. Modeling the impact of climate variability on diarrhea-associated diseases in Taiwan (1996-2007). Sci Total Environ. 2010; 409:43-51

104. Semenza JC, Suk JE, Estevez V, Ebi KL, Lindgren E. Mapping climate change vulnerabilities to infectious disease in Europe. Environ Health Perspect. 2012;120:385-92. 
105. Cheng JJ. Berry P. Health co-benefits and risks of public health adaptation strategies to climate change: a review of current literature. Int J Public Health. 2013;58:305-11.

106. Pucher J, Buehler R, Bassett DR, Dannenberg AL. Walking and cycling to health: a comparative analysis of city, state, and international data. Am J Pub Health. 2010;100: 1986-92.

107. Grabow ML, Spak SN, Holloway TA, Stone B (JR), Mednick AC, Patz JA. Air quality and exercise-related health benefits from reduced car travel in the Midwestern United States. Environ Health Perspect. 2012;120:68-76.

108. Diamond-Smith N, Potts M. A woman cannot die from a pregnancy she does not have. Int Perspect Sex Reprod Health. 2011;37:155-7.

109. Prata N. Making family planning accessible in resource-poor settings. Philos Trans R Soc Lond B Biol Sci. 2009;364:3093-9.

110. Woodward A, Lindsay G, Singh S. Adapting to climate change to sustain health. WIREs Clim Change. 2011;2:271-82.

111. Lowe D, Ebi KL, Forsberg B. Heatwave early warning systems and adaptation advice to reduce human health consequences of heatwaves. Int J Environ Res Public Health. 2011; 8:4623-48.

112. McMichael C, Barnett J, McMichael AJ. An ill wind? Climate change, migration, and health. Environ Health Perspect. 2012;120:646-54.

113. McMichael AJ, McMichael C, Berry H, Bowen K. Climate-related displacement: health risks and responses. In: McAdam J, (editor). Climate Change and Displacement: Multidisciplinary Perspectives. Oxford: Hart Publishing; 2010. p.191-219.

114. Locke JT. Climate change-induced migration in the Pacific region: sudden crisis and long-term developments. Geogr J. 2009;175:171-80. 